\title{
Profile of Moodle Based Evaluation Media on Mathematics Learning at SMA Muhammadiyah Al-Amin Kota Sorong
}

\author{
Muhammad Fathurrahman ${ }^{1}$, Rahmatullah Bin Arsyad ${ }^{1}$, Arie Anang Setyo ${ }^{1}$, Muhammad \\ Syahrul Kahar ${ }^{1}$, Zakiyah Anwar ${ }^{1}$, Mulyono $^{1}$, Ahmad Wael $^{2}$ and Mursalin ${ }^{3}$ \\ \{r.fathur.ums@gmail.com\}
${ }^{1}$ Department of Mathematics Education, Universitas Muhammadiyah Sorong,West Papua, Indonesia ${ }^{2}$ Department of English Education, Universitas Muhammadiyah Sorong, West Papua, Indonesia ${ }^{3}$ Department of Mathematics Education, Universitas Malikussaleh, Aceh Utara, Indonesia

\begin{abstract}
This research was a research development which produced the product of evaluation media used LMS Moodle. This research was conducted at SMA Muhammadiyah Al-Amin of Sorong city with the subject of the research were students of grade XII IPA.The model of development chosen was the model which developed by Alessi and Trollip. The result showed that (i) result of media evaluation on learning has valid because validation result was on interval $2,5 \leq \mathrm{M}<3,5$. Based on all average score 3,3it means that, the component which validated including on category "Valid". (ii) learning device has practiced because of the average of questionnaire percentage was 90\% which means the teacher responds "High Positive" towards evaluation media which developed. (iii) evaluation media on learning has effective because the result of all students' respondsincluding expected criteria.
\end{abstract}

Keywords: Evaluation Media, Moodle, Mathematics Learning

\section{Introduction}

The development of globalization rapidly was impacts towards changes in all aspects of human, The change also felt by the aspect of the economy, social, culture, education and so on. The demands of the globalization of development as indirect demands so that all the aspects adjust with the demands of development and the progress of time, especially in education sector should be updated in line with the development of time in globalization era.

This change supports the world of education has to have innovations which suitable for the development of time. The innovations could be applied in all national education system. In curriculum, teacher, learning process and also assessment. The government generally, and especially to educational actors should be self-adjusted with some progress who able to increase quality andeducationaloutput. Some positive things could be felt based on the development of globalization especially in educational sector is easier in finding learning sources, more choiceto use ICT in learning, it was used in order to increase a part of media and multimedia on learning, these devices of learning were cover some media such as learning 
opportunity is flexible, learning based computer (CBI), mobile learning, e-learning, learning management system and etc.

Innovations which developed should not focus on innovation in the learning process, but it is involved all aspects to determine learning outcomes which need the innovation in learning phase. This in line with [1] who proposed that evaluation activity become more crucial to determine whether the activity which succeeds to be done or not.The Evaluation also covers decision about how to know students' learning outcomes, when do it, and anything which is known.

Based on the observation at SMA Muhammadiyah Al Amin of Sorong city, teacher evaluated students' learning outcomes who still used conventional way, like the question made in form of paper, and the assessment was still done manually.This way, of course, needsa long time from making of evolution sheets till evaluation of assessment sheets. Based on that problem, it was needed to be developed a media which can help the teacher to do the evaluation of students' learning outcomes, the media was Moodle (Modular Object-Oriented Dynamic Learning Environment) is designed by using the principles of pedagogy to help educators in making the system of e-learning which effective[2].

Moodle is a name for an application program which can change the process of learning and evaluation of learning outcomes in web form. This application allows the students enter to "classroom" digital for accessing learningmaterials, exercises question.Moodle can be used as learning materials, quiz, and others could be gained through internet.(Taylor et al., 2011) proposed that learning based moodle sometimes has many benefits to the students. If it was designed good and proper, so the learning based moodle can be fun learning, have high activity element, caused the students remembering more learning materials.

\section{Methods}

The Development of Model which is used in developing an evaluation media based Moodle.This moodle is model which developed by Alessi and Trollip. The development step which done in this research wasa design of planning stage and development. Population and sample in this research were the students of class XII IPA SMA Muhammadiyah Al-Amin SorongCity. The criteria validation and product feasibility were, (1) Determine the category of validation in every aspect or all aspects by matching the average criteria $\left(\bar{K}_{l}\right)$ or average aspect $\left(\bar{A}_{l}\right)$ or total average $\bar{x}$ with validation category which was set. (2) Validation category in every criteria,every aspect, or all aspects was set as follows:

$$
\begin{array}{ll}
3,5 \leq \mathrm{M} \leq 4 & : \text { strong valid } \\
2,5 \leq \mathrm{M}<3,5 & : \text { valid } \\
1,5 \leq \mathrm{M}<2,5 & \text { : enough valid } \\
\mathrm{M}<1,5 & : \text { not valid }
\end{array}
$$

Keterangan :

$\mathrm{GM}=\bar{K}_{\iota}$, for finding of validation every criteria,

$\mathrm{M}=\bar{A}_{l}$, for finding of validation every aspect,

$\mathrm{M}=\bar{X}$, for finding of validation all aspects,

Determining the category of positive respond based on a percentage which is obtained by respond category that is used as follows:

$\begin{array}{ll}85 \% \leq \mathrm{RT} & : \text { Strong Positive } \\ 70 \% \leq \mathrm{RT}<85 \% & \text { : Positive }\end{array}$


$\begin{array}{ll}50 \% \leq \mathrm{RT}<70 \% & : \text { Enough Positive } \\ \mathrm{RT}<50 \% & : \text { Not Positive }\end{array}$

\section{Results and Discussion}

The data of this study was described as in the following figures.

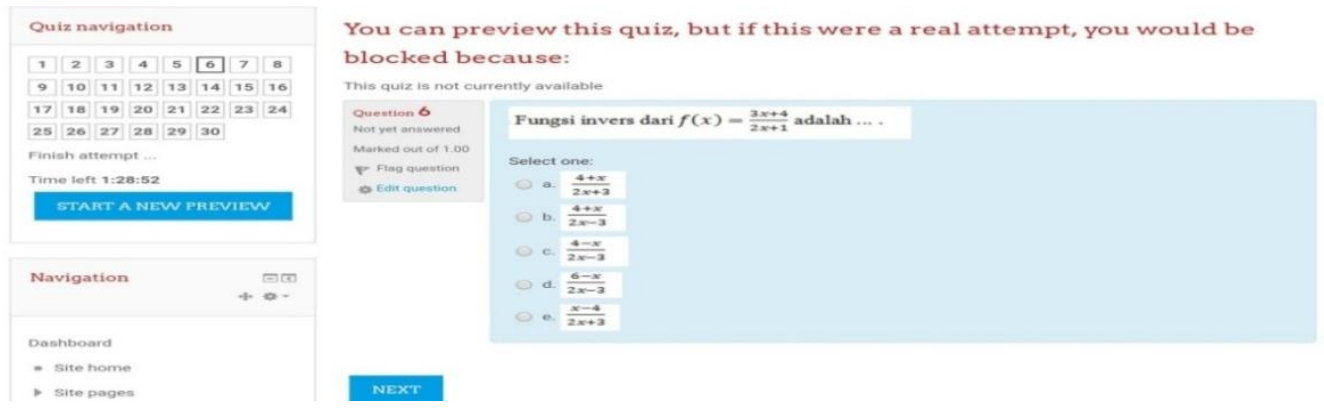

Figures 1: Evaluation Media based website moodle

This media was developed used LMS Moodle which has features, which can help the teacher to make the exam question of computer based test (CBT) in order to students' learning outcomes can be carried with effectively and efficiently. [4], [5] explain that the use of assessment systemof learning outcomes usingMoodle can help in assessing and able to give repairing to result that students got. Based on the questionnaire result which has given to 3 experts were obtained score analysis as follows:

\section{Result Validation of Learning Material Aspect}

- Series1

Material can be generalized Feedback form Cognitive ability Motivation Question instruction Provision / content Conformity of material

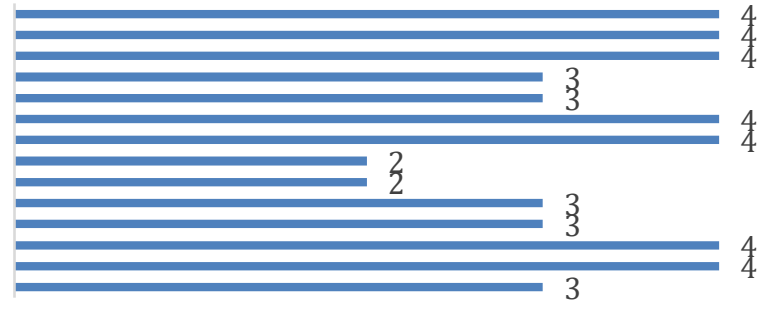

Figures 2. Evaluation Media based website moodle

Validation score by the expert of material was 47 with average 3.4. Based on the criteria of validation that the average score of this assessment was in category "Valid" $(2,5 \leq M<3,5)$. Then, it can be stated as validation criteria. So that evaluation media that the researcher developed and proper to use in implementing on exam implementation at school. 
The result of feasibility was strengthened by [4] stated that the use of Moodle can help a teacher in giving the learning evaluation.

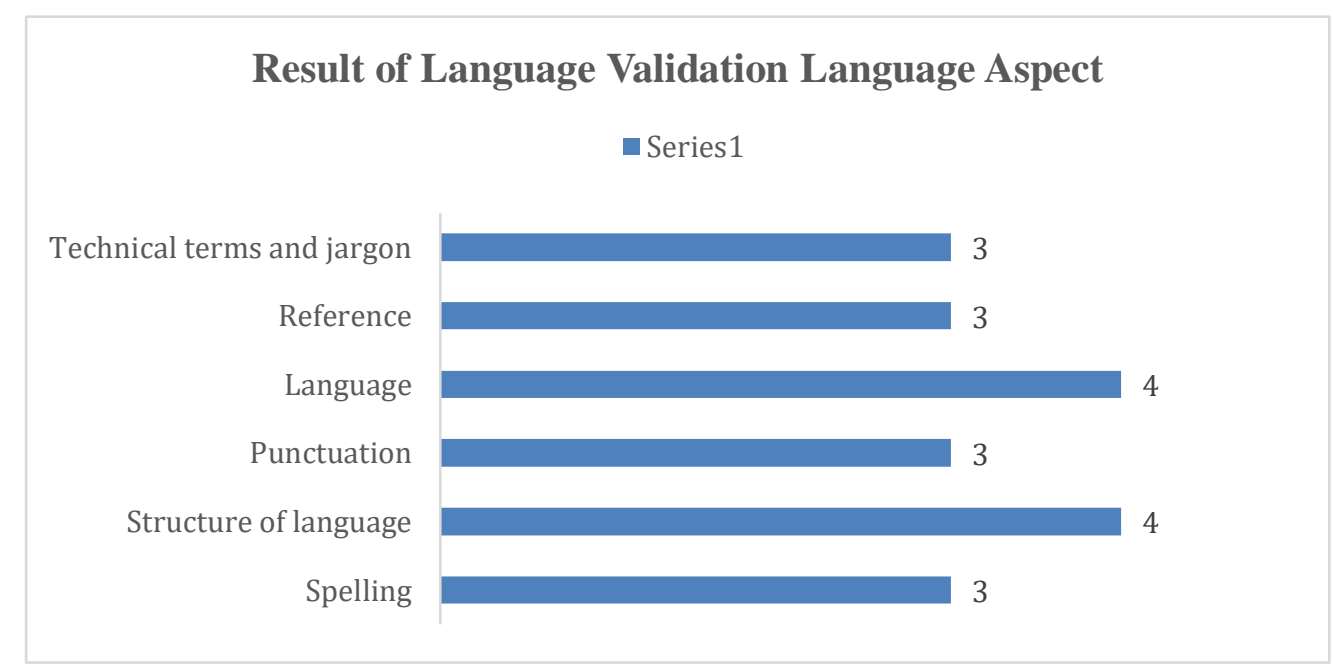

Figures 3. Validation Result Language aspect

The assessment from the language expert towards evaluation media which developedhas number $\mathrm{h}$ of score 20 with the average 3.3. Based on validation criteria that the average of assessment was in category "Valid" $(2.5 \leq \mathrm{M}<3.5)$. Then it can be stated as meeting criteria of validation.

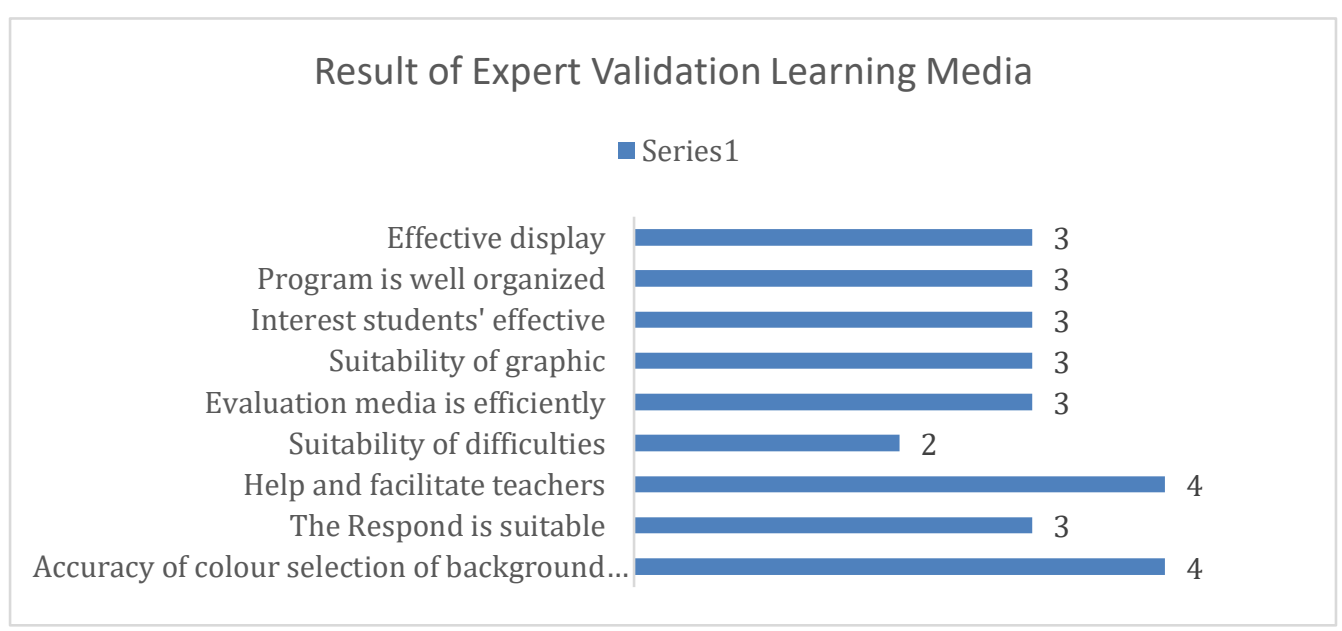

Figures 4. Result Validation of Learning Aspect Media

The assessment from the expert of evaluation towards evaluation media which is developed had the score 28 with the average 3.1.This phase is supported by the research [6]stated that the description of ability and the students in the class can be improved through 
evaluation process used Moodle.Based on the criteria of validation, The average of assessment category was "Valid" $(2.5 \leq \mathrm{M}<3.5)$. So that it can be stated as meeting the validation criteria.

Table 1. Questionnaire Score of Teacher

\begin{tabular}{|c|l|c|c|}
\hline No & \multicolumn{1}{|c|}{ Indicator } & Percentage & Category \\
\hline 1 & $\begin{array}{l}\text { Do the use of evaluation media based website memorable } \\
\text { to the teachers towards evaluation process on learning? }\end{array}$ & $100 \%$ & $\begin{array}{c}\text { Strongly } \\
\text { Agree }\end{array}$ \\
\hline 2 & $\begin{array}{l}\text { Do the use of evaluation media on learning outcomes } \\
\text { based website Moodle ease to be operated? }\end{array}$ & $75 \%$ & Agree \\
\hline 3 & $\begin{array}{l}\text { Is there any advantage from evaluation media based } \\
\text { website Moodle if it is compared with evaluation media } \\
\text { used paper? }\end{array}$ & $75 \%$ & Agree \\
\hline 4 & $\begin{array}{l}\text { Is the process accurate on assessment and easiest } \\
\text { compare with assessment manually? }\end{array}$ & $100 \%$ & $\begin{array}{c}\text { Strongly } \\
\text { Agree }\end{array}$ \\
\hline 5 & $\begin{array}{l}\text { Do the teachers interested in using evaluation media base } \\
\text { Moodleon further examination? }\end{array}$ & $100 \%$ & $\begin{array}{c}\text { Strongly } \\
\text { Agree }\end{array}$ \\
\hline & \multicolumn{2}{|c|}{ Average } & High Positive \\
\hline
\end{tabular}

Evaluation of questionnaire on teachers' respond was done after examination process used evaluation media basedMoodle which developed by the researcher. Based on the data of the result from teachers' respond in questionnaire It can be concluded the average score on the percentage of the result on teachers' respond was $90 \%$. Based on the practical criteria, the percentage of this assessment was in the category "High Positive" $(85 \% \leq \mathrm{RT})$. Then it can be said that evaluation media base website moodle fill the practical criteria and can be used in exam implementation at school.This in line with [7], (Pe, Farin, and Bolay, 2014)proposed the use ofmoodle in evaluation learning process and it can be seen the differences on students' ability and the activities were done during the learning process.

Table 2. The Score of Students' questionnaire

\begin{tabular}{|c|l|c|c|}
\hline No & \multicolumn{1}{|c|}{ Indicator } & Percentage & Category \\
\hline $\mathbf{1}$ & $\begin{array}{l}\text { This evaluation media used the easiest language to } \\
\text { understand }\end{array}$ & $70 \%$ & Agree \\
\hline $\mathbf{2}$ & $\begin{array}{l}\text { Evaluation media used the sentences which showed } \\
\text { the double meaning }\end{array}$ & $78 \%$ & $\begin{array}{c}\text { Strongly } \\
\text { Agree }\end{array}$ \\
\hline $\mathbf{3}$ & $\begin{array}{l}\text { Instruction of activity in clear evaluation media, So } \\
\text { that makes me ease to make all these activities. }\end{array}$ & $68 \%$ & Agree \\
\hline $\mathbf{4}$ & $\begin{array}{l}\text { Type letter selection, size, and space which is used } \\
\text { to make me ease in reading the questions. }\end{array}$ & $\begin{array}{c}\text { Strongly } \\
\text { Agree }\end{array}$ \\
\hline $\mathbf{5}$ & $\begin{array}{l}\text { An affordable internet network } \\
\mathbf{6}\end{array}$ & $\begin{array}{l}\text { When using this evaluation media, there is } \\
\text { something interest for me }\end{array}$ & Agree \\
\hline $\mathbf{7}$ & Presenting style of this evaluation media not bored & $78 \%$ & Strongly \\
\hline
\end{tabular}




\begin{tabular}{|c|c|c|c|}
\hline & & & Agree \\
\hline 8 & $\begin{array}{l}\text { In every word question or sentences and easy to } \\
\text { understand }\end{array}$ & $75 \%$ & Agree \\
\hline 9 & The question which presented was benefited for me & $78 \%$ & $\begin{array}{l}\text { Strongly } \\
\text { Agree }\end{array}$ \\
\hline 10 & $\begin{array}{l}\text { Material in evaluation media can make me } \\
\text { understand }\end{array}$ & $78 \%$ & $\begin{array}{l}\text { Strongly } \\
\text { Agree }\end{array}$ \\
\hline \multicolumn{2}{|r|}{ Average } & $76 \%$ & Positive \\
\hline
\end{tabular}

The evaluation of students' respond was done after the process of final examination by using evaluation media based moodle. Based on the data of the result on students' questionnaire respond which given to 10 students, it can be concluded that the average of score percentage on the questionnaire was $76 \%$. Respond category was $70 \% \leq \mathrm{RT} \leq 85 \%$, which mean the average of students' positive respond towards evaluation media base website used in this research. This means that the media was developed fill the effective criteria.[9]propose that students gave good respond towards the use of moodle in learning evaluation, besides that the quality of an evaluationlearning process well obtained in improving students' motivation.

The result of an experiment on evaluation media in the mathematics learning basedmoodle, it is very interesting for teachers and students because this is a new thing, where the students can do the exam only using headphone, tablet or laptop that they had, besides that the ability to access in everywhere make moodle easiest to use. [10] explained that the use of moodle is very helpful students in collaborating to establish the concept and solve the problem in learning.

\section{Conclusions}

The development of evaluation media base website moodlesfor mathematics learning at students of grade XII SMA Muhammadiyah Al-Amin SorongCity already develop on development criteria. This media was developed by involving 3 validators which consist of expert media, language expert and the material expert had stated that the media was developed could be carried to evaluation criteria on category "valid". As for the result of respond teachers and students said that the media which developed could be used in the implementation of learning outcomes.

\section{References}

[1] A. Iglesias and L. Moreno, "Accessibility barriers for users of screen readers in the Moodle learning content management system," Springer-Verlag Berlin Heidelb., 2013.

[2] M. Katsamani, S. Retalis, and M. Boloudakis, "Designing a Moodle course with the CADMOS learning design tool," EMI. Educ. Media Int., vol. 49, no. 4, pp. 317-331, 2012.

[3] P. Taylor, Á. Mora, E. Mérida, and R. Eixarch, "International Journal of Mathematical Random learning units using WIRIS quizzes in Moodle," Int. J. Math. Educ. Sci. Technol., vol. 42, no. 6, pp. 751-763, 2011.

[4] N. Yusof, N. Ariffin, M. Zin, and N. Shyahira, “Java Programming Assessment Tool for 
Assignment Module in Moodle E-learning System," Procedia - Soc. Behav. Sci., vol. 56, pp. 767773, 2012.

[5] G. M. Amandu, J. K. Muliira, and D. C. Fronda, "Using moodle e-learning platform to foster student self-directed learning: Experiences with utilization of the software in undergraduate nursing courses in a Middle Eastern university," Procedia - Soc. Behav. Sci., vol. 93, pp. 677-683, 2013.

[6] T. Delia, "Deploying Moodle Capabilities to Showcase Interactive Content and Language Learning in the Engineering Students 'Foreign Language Training," Procedia Soc. Behav. Sci., vol. 15, pp. 1153-1157, 2011.

[7] T. Martín-blas and A. Serrano-fernández, "Computers \& Education The role of new technologies in the learning process : Moodle as a teaching tool in Physics," Comput. Educ., vol. 52, no. 1, pp. 35-44, 2009.

[8] A. Pe, G. Farin, and N. Le Bolay, "Supporting Students ' Learning To Learn in General Chemistry Using Moodle,” J. Chem. Educ., pp. 1823-1829, 2014.

[9] and C. H. C. Hui Hui Chen, Ming Che Lee, Yun Lin Wu, Jing Yao Qiu, Cheng He Lin, Hong Yong Tang, "An Analysis of Moodle in Engineering Education : The TAM Perspective Session $\mathrm{H} 1 \mathrm{C}$," in IEEE International Conference on Teaching, Assessment, and Learning for Engineering (TALE) 2012 H1C-1, 2012, pp. 1-5.

[10] A. Helena, S. Sonego, É. Marcelo, F. B. Nunes, and G. B. Voss, "Use of Moodle as a Tool for Collaborative Learning: A Study Focused on Wiki," in IEEE REVISTA IBEROAMERICANA DE TECNOLOGIAS DEL APRENDIZAJE, 2014, vol. 9, no. 1, pp. 17-21. 
